\title{
Pengaruh Husnuzzhan Terhadap Perilaku Prososial Pada Mahasiswa UIN Antasari
}

\author{
Mariatul Kiftiah, Mubarak, dan Yulia Hairina \\ Universitas Islam Negeri Antasari Banjarmasin
}

\begin{abstract}
This study aims to determine the effect of husnuzzhan on prosocial behavior in students of UIN Antasari Banjarmasin. This type of research is field research with a quantitative approach. The population in this study were active students of UIN Antasari Banjarmasin class 2018 and 2019. The sampling technique uesd was purposive sampling. The sample of this study amounted to 98 people. Based on the research conducted, the results obtained: 1) The level of husnuzzhan in the high category was 18 people (18,4\%), while 68 people $(69,4 \%)$ and low 12 people (12,2\%). 2) The level of prosocial behavior in the high category was 11 people $(11,2 \%)$, while 73 people $(75,5 \%)$ and low 14 people $(14,3 \%) .3)$ There is a husnuzzhan influence on prosocial behavior in UIN Antasari Banjarmasin students with a significance value of 0,000 (sig < 0,05) and a effective contribution of 21,9\%.
\end{abstract}

Keywords: Husnuzzhan; Prosocial Behavior; UIN Antasari Student.

\begin{abstract}
Abstrak
Penelitian ini bertujuan untuk mengetahui pengaruh husnzzhan terhadap perilaku prososial pada mahasiswa UIN Antasari Banjarmasin. Jenis penelitian ini adalah penelitian lapangan (field research) dengan pendekatan kuantitatif. Populasi dalam penelitian ini adalah mahasiswa aktif UIN Antasari Banjarmasin angkatan 2018 dan 2019. Teknik sampling yang digunakan adalah purposive sampling. Sampel penelitian ini berjumlah 98 orang. Berdasarkan penelitian yang dilakukan, maka didapatkan hasil: 1) Tingkat husnuzzhan pada kategori tinggi sebanyak 18 orang (18,4\%), sedang 68 orang $(69,4 \%)$ dan rendah 12 orang $(12,2 \%)$. 2$)$ Tingkat perilaku prososial pada kategori tinggi sebanyak 11 orang $(11,2 \%)$, sedang 73 orang $(74,5 \%)$ dan rendah 14 orang (14,3\%). 3) Terdapat pengaruh husnuzzhan terhadap perilaku prososial pada mahasiswa UIN Antasari Banjarmasin dengan nilai signifikansi 0,000 (sig < $0,05)$ dan sumbangan efektif sebesar $21,9 \%$.
\end{abstract}

Kata Kunci: Husnuzzhan; Perilaku Prososial; Mahasiswa UIN Antasari.

Manusia adalah makhluk sosial yang saling ketergantungan antara individu yang satu dengan yang lainnya. Oleh karena itu, manusia tidak dapat memutuskan hubungan dengan sesamanya dan hidup dalam kesendirian untuk mempertahankan kelangsungan hidupnya. Selain itu, manusia dapat berkontribusi dalam pembangunan dan pengembangan kehidupan masyarakat yang lebih sejahtera, seperti membantu masyarakat yang kesusahan dan tolong menolong antar sesama. Perilaku menolong dikenal dengan perilaku prososial, perilaku prososial adalah perilaku membantu orang lain yang sedang 
membutuhkan bantuan tanpa mengharapkan manfaat atau imbalan apapun dari yang ditolong (Hanurawan, 2018).

Menurut Eisenberg perilaku prososial adalah perilaku membantu, berbagi dan perilaku positif lainnya yang terlihat disengaja dan sukarela serta dapat memiliki motif yang tidak ditentukan (Hafiz, 2018). Menurut Baron dan Branscombe perilaku prososial adalah tindakan individu untuk menolong orang lain yang sering kali dilakukan tanpa memberi manfaat langsung pada diri si penolong (Tim Penulis Fakultas Psikologi UI, 2011). William menjelaskan bahwa perilaku prososial adalah perilaku yang memiliki kecenderungan untuk mengubah keadaan fisik atau psikologis penerima bantuan dari yang kurang baik menjadi lebih baik dalam arti secara materi maupun psikologis (Yantiek, 2014).

Menolong orang lain merupakan salah satu norma sosial bagi setiap individu dimasyarakat. Apalagi sebagai mahasiswa, seseorang yang sudah mempersiapkan diri untuk memasuki dunia sosial maupun dunia kerja, yang mana dituntut untuk mampu berperan secara aktif dan positif. Mahasiswa sebagai kaum intelektual dituntut dapat responsive terhadap permasalahan yang dihadapi oleh masyarakat. Melalui pengetahuan yang dimiliki, mahasiswa diharapkan tergerak kepeduliannya untuk mencermati permasalahan dan mengupayakan solusi yang menguntungkan masyarakat.

Namun pada faktanya, berdasarkan pengamatan yang dilakukan peneliti. Masih menemukan beberapa ketidakpedulian mahasiswa pada hal-hal kecil, seperti tidak membantu temannya yang kesusahan saat ingin mengeluarkan kendaaran dari area parkir, menghalangi jalan lewat di lorong fakultas dan kantin. Akan tetapi, disisi lain juga masih ada mahasiswa yang memiliki kepedulian dalam hal menolong orang lain di lingkungan kampus.

Daniprawiro menjelaskan bahwa menipisnya perilaku prososial sebagai bentuk kepedulian moral yang muncul di masyarakat, baik dikalangan dewasa maupun remaja. Budaya tradisional yang dikenal dengan gotong royong kini dengan cepat berubah menjadi sifar egoistik, individualistik ataupun masa bodoh serta tidak mau lagi peduli dengan yang terjadi di sekitarnya (Daniprawiro, 2009). Sejalan dengan yang dipaparkan dalam penelitian Nufus (2012) yang dikutip oleh Nurhafiza, ia menemukan bahwa sebagian santri di Pesantren Nurul Ummah Kotagede, Yogyakarta semakin individualis. Hal ini dilihat dari beberapa kasus diantaranya RU (20 tahun) ketika sakit terpaksa pergi berobat sendiri karena 
tidak ada teman yang bersedia mengantar ke dokter. Kasus lainnya AZ (16 tahun) mengaku bahwa ia cenderung hanya menolong teman yang satu kamar dengannya, jika ada teman lain yang sakit terkadang ia tidak mengetahuinya dengan alasan tidak terlalu dekat dengan orang tersebut (Nurhafiza, 2019).

Hal ini sejalan dengan wawancara yang dilakukan peneliti kepada mahasiswa L bahwa ia hanya menolong orang-orang yang hanya dikenalnya saja. Selain itu mahasiswa $\mathrm{H}$ mengatakan bahwa ia juga segan untuk membantu dalam memberi tumpangan kepada mahasiswa yang tidak dikenalnya. Apalagi di masa pandemi sekarang, biasanya muncul stigma sosial terhadap seseorang yang mengalami gejala tertentu dan terindikasi suatu penyakit, meskipun belum dipastikan terjangkit virus Covid 19. Hal ini terjadi karena manusia cenderung takut dan waspada terhadap suatu hal yang belum diketahuinya ataupun melakukan prejudgement terlebih dahulu sebelum mengetahui fakta yang sebenarnya. Sehingga tanpa disadari, manusia tidak terlepas dari kebiasaan berprasangka terhadap segala sesuatu yang dihadapinya. Sehingga tidak jarang seseorang menyukai atau membenci sesuatu hanya berdasarkan prasangka, tanpa terlebih dulu mencari fakta yang sebenarnya (Sagir, 2009).

Prasangka mengandung sikap, pikiran, keyakinan, dan kepercayaan seseorang yang didasarkan pada penilaian pendahuluan (prejudgement) yang dilakukan sebelum mengetahui banyak tentang karakteristik seseorang (Amanda \& Mardianto, 2014). Maka diperlukan sikap memahami untuk menghindari sikap prasangka tersebut. Dengan selalu berpikir positif memudahkan individu untuk beraktivitas dengan baik, karena dengan berpikir positif akan mendorong seseorang untuk melakukan hal-hal yang positif.

Berpikir positif dalam Islam dikenal dengan istilah Husnuzzhan. Husnuzzhan adalah salah satu akhlak terpuji yang memiliki arti berbaik sangka (Anwar, 2010). Islam mengajarkan umatnya untuk senantiasa berbaik sangka dengan apa yang dihadapi, baik ketika berinteraksi dengan sesama manusia maupun menghadapi takdir Allah swt. Husnuzzhan menjadi suatu landasan untuk manusia agar selalu berfikir positif atas segala peristiwa yang telah dialami (Faliyandra, 2019). Islam telah mengatur adab-adab tentang pergaulan dan sopan santun baik bermasyarakat atau berindividu yang harus dijunjung tinggi oleh segala lapisan masyarakat. 
Berdasarkan pemaparan tersebut, maka peneliti tertarik melakukan penelitian mengenai pengaruh husnuzzhan terhadap perilaku prososial pada Mahasiswa UIN Antasari Banjarmasin.

\section{Metode}

Metode yang digunakan dalam penelitian ini adalah metode kuantitatif dengan jenis penelitian lapangan (field research). Lokasi penelitian bertempat di UIN Antasari Banjarmasin Jalan Ahmad Yani KM 4,5 Banjarmasin. Subjek dalam penelitian ini adalah mahasiswa aktif UIN Antasari Banjarmasin angkatan 2018 dan 2019. Objek dalam penelitian ini adalah variabel husnuzzhan dan variabel perilaku prososial.

Populasi dalam penelitian ini adalah seluruh mahasiswa aktif UIN Antasari Banjarmasin yang berjumlah 5.610 orang berdasarkan rekapitulasi data mahasiswa tahun 2019/2020. Jumlah sampel yang diambil berdasarkan rumus Slovin dengan tingkat kesalahan $10 \%$ didapat 98 orang dari jumlah populasi mahasiswa aktif. Teknik pengambilan sampel dalam penelitian ini menggunakan teknik purposive sampling yaitu pengambilan sampel dengan karakteristik tertentu. Adapun kriteria yang ditentukan peneliti adalah mahasiswa aktif UIN Antasari angkatan 2018 dan 2019 yang berusia antara 18-22 tahun.

Pengumpulan data dalam penelitian ini menggunakan dua alat ukur yakni skala husnuzzhan dan skala perilaku prososial yang sudah melalui tahap professional judgement, try out, uji validitas dan uji reliabilitas. Skala husnuzzhan yang digunakan peneliti adalah alat ukur yang telah dimodifikasi berdasarkan pada aspek-aspek yang dikemukakan oleh Rusydi yaitu husnuzzhan kepada Allah swt dan husnuzzhan kepada sesama manusia (Rusydi, 2012). Skala perilaku prososial disusun berdasarkan pada aspek-aspek yang dikemukakan oleh Carlo dan Randall antara lain, altruisme, emotional, compliant, public, anonymous dan dire.

Uji validitas dilakukan dengan menggunakan bantuan software SPSS 22 kepada 40 responden. Berdasarkan $\mathrm{r}$ tabel dengan taraf sigifikansi 5\% dan jumlah responden sebanyak 40 maka nilai validitasnya adalah 0,312. Uji reliabilitas dilihat dari nilai cronbach's alpha, jika nilai Alpha > 0,6 maka skala tersebut reliabel. Hasil dari uji reliabilitas skala husnuzzhan adalah 0,935 dan skala perilaku prososial 0,785.

Sumber data dalam penelitian ini terdiri dari dua yaitu data primer dan data sekunder. Data primer adalah data yang didapatkan dari responden penelitian, sedangkan data sekunder didapatkan dari literatur yang berkaitan dengan penelitian ini. Analisis data 
penelitian ini menggunakan analisis statistika. Analisis statistika yang digunakan untuk menguji hipotesis penelitian adalah analisis regresi linear sederhana. Analisis regresi linear sederhana digunakan untuk menguji pengaruh satu variabel independen terhadap variabel dependen.

\section{H a s i 1}

Responden dalam peneltian ini adalah mahasiswa aktif UIN Antasari Banjarmasin angkatan 2018 dan 2019 usia 18-22 tahun. Jumlah responden sebanyak 98 orang.

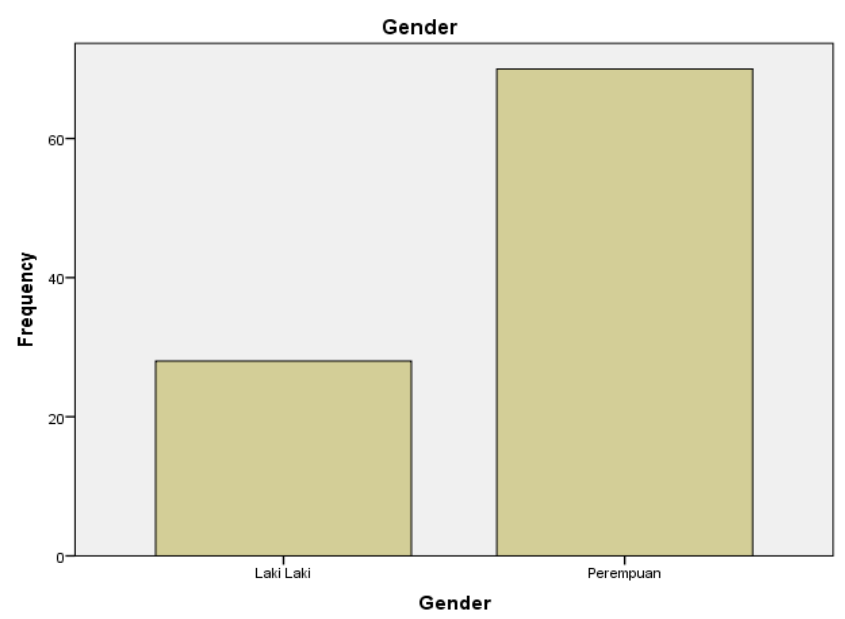

\section{Gambar 1. Diagram Jenis Kelamin Responden}

Berdasarkan gamabar 1, jumlah responden perempuan dalam penelitian ini lebih banyak dibandingkan laki-laki dengan jumlah perempuan sebanyak 70 orang dan laki-laki sebanyak 28 orang.

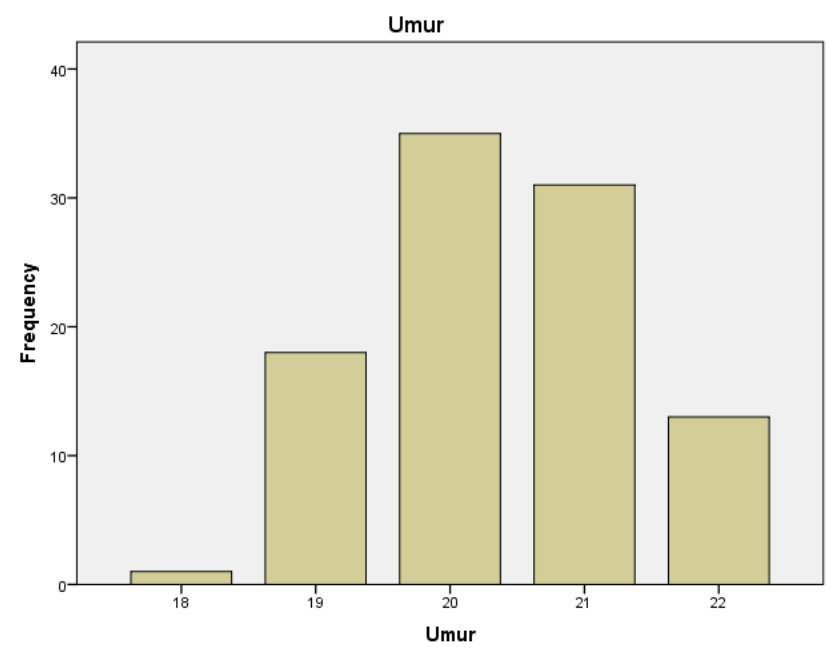

Gambar 2. Diagram Umur Responden 
Berdasarkan gambar 2, responden penelitian ini adalah mahasiswa yang berusia 1822 tahun. Sebagian besar responden berusian 20 tahun dan yang terendah berusia 18 tahun.

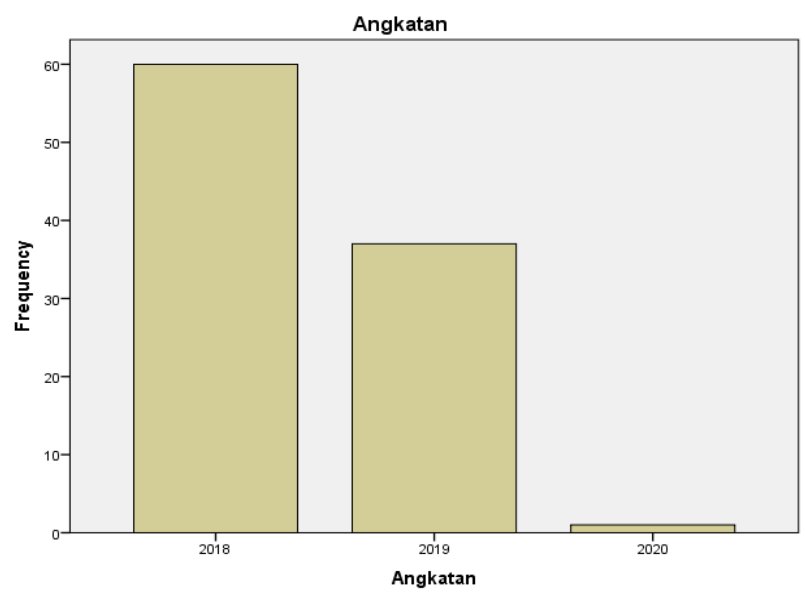

\section{Gambar 3. Diagram Angkatan Responden}

Berdasarkan gambar 3, mahasiswa angkatan 2018 sebanyak 60 orang, mahasiswa angkatan 2019 sebanyak 37 orang dan mahasiswa angkatan 2020 sebanyak 1 orang.

Tabel 1

Tingkat Husnuzzhan

\begin{tabular}{lccc}
\hline Kategori & Norma & Frekuensi & Persentase \\
\hline$X<83,2$ & Rendah & 12 & $12,2 \%$ \\
$83,2 \leq X<99,4$ & Sedang & 68 & $69,4 \%$ \\
$X>99,4$ & Tinggi & 18 & $18,4 \%$ \\
\hline
\end{tabular}

Berdasarkan hasil tabel 1 diketahui bahwa tingkat husnuzzhan mahasiswa UIN Antasari Banjarmasin pada kategori rendah sebanyak 12 orang dengan persentase 12,2\%, kategori sedang sebanyak 68 orang dengan persentase 69,4\% dan kategori tinggi sebanyak 18 orang dengan persentase $18,4 \%$.

Tabel 2

Tingkat Perilaku Prososial

\begin{tabular}{lccc}
\hline Kategori & Norma & Frekuensi & Persentase \\
\hline$X<81,9$ & Rendah & 14 & $14,3 \%$ \\
$81,9 \leq X<96,6$ & Sedang & 73 & $74,5 \%$ \\
$X>96,6$ & Tinggi & 11 & $11,2 \%$ \\
\hline
\end{tabular}


Berdasarkan hasil tabel 2 diketahui tingkat perilaku prososial mahasiswa UIN Antasari Banjarmasin berada pada kategori rendah sebanyak 14 orang dengan persentase $14,3 \%$, kategori sedang sebanyak 73 orang dengan persentase $74,5 \%$ dan kategori tinggi sebanyak 11 orang dengan persentase $11,2 \%$.

Tabel 3

Tabel Normalitas

\begin{tabular}{l|lr}
\hline & & \multicolumn{2}{|c}{ Unstandardized Residual } \\
\hline$N$ & Mean & 98 \\
Normal Parameters, &, 0000000 \\
& Std. Deviation & 6,47274133 \\
Most Extreme Differences & Absolute &, 075 \\
& Positive &, 075 \\
& Negative &,- 052 \\
Test Statistic &, 075 \\
Asymp. Sig. (2-tailed) &, 200 \\
\hline
\end{tabular}

Berdasarkan hasil tabel 3 diketahui bahwa nilai signifikansi pada variabel husnuzzhan dan variabel perilaku prososial adalah 0,200 (nilai sig > 0,05), maka dapat ditarik kesimpulan bahwa nilai residual kedua variabel tersebut berdistribusi normal.

Tabel 4

Uji Linearitas

\begin{tabular}{|c|c|c|c|c|c|c|c|}
\hline & & & $\begin{array}{l}\text { Sum of } \\
\text { Squares }\end{array}$ & $d f$ & $\begin{array}{l}\text { Mean } \\
\text { Square }\end{array}$ & $F$ & Sig. \\
\hline \multirow{5}{*}{$\begin{array}{l}\text { Perilaku Prososial * } \\
\text { Husnuzzhan }\end{array}$} & Between & (Combined) & 2173,666 & 25 & 86,947 & 2,065 & ,009 \\
\hline & Groups & Linearity & 1140,867 & 1 & 1140,867 & 27,099 & ,000 \\
\hline & & $\begin{array}{l}\text { Deviation } \\
\text { from Linearity }\end{array}$ & 1032,799 & 24 & 43,033 & 1,022 & ,452 \\
\hline & Within & oups & 3031,150 & 72 & 42,099 & & \\
\hline & Total & & 5204,816 & 97 & & & \\
\hline
\end{tabular}

Berdasarkan hasil tabel 4 diketahui kedua variabel memiliki nilai sebesar 0,452 (nilai sig $>0,05)$ sehingga dapat ditarik kesimpulan bahwa variabel husnuzzhan dan variabel perilaku prososial memiliki hubungan yang linear.

Tabel 5

Uji Hipotesis

\begin{tabular}{lccccc}
\hline Model & Sum of Squares & Df & Mean Square & $F$ & Sig. \\
\hline Regression & 1140,867 & 1 & 1140,867 & 26,950 &, $000^{\mathrm{b}}$ \\
Residual & 4063,949 & 96 & 42,333 & &
\end{tabular}


Berdasarkan hasil tabel 5 diketahui bahwa nilai $F_{\text {hitung }}=26,950$ dengan nilai signifikansi sebesar 0,000 (nilai sig < 0,05) maka hal ini menunjukkan bahwa Ha diterima, sehingga dapat ditarik kesimpulan bahwa terdapat pengaruh yang signifikan antara variabel husnuzzhan terhadap variabel perilaku prososial.

Tabel 6

Uji Analisis Determinan

\begin{tabular}{lrrrrr}
\hline Model & $R$ & R Square & Adjusted $R$ & Square & Std. Error of the Estimate \\
\hline 1 &, $468^{\mathrm{a}}$ &, 219 &, 211 & 6,506
\end{tabular}

Berdasarkan hasil tabel 6, diketahui nilai $R$ Square sebesar 0,219 nilai tersebut menunjukkan bahwa variabel husnuzzhan memberikan sumbangan efektif sebesar 21,9\% terhadap variabel perilaku prososial.

\section{Pembahasan}

Menurut Baron dan Branscombe perilaku prososial adalah perilaku menolong orang lain yang sering kali dilakukan tanpa memberi manfaat langsung pada diri si penolong. Eisenberg memaparkan bahwa perilaku prososial biasanya digunakan untuk menjelaskan perilaku menolong dan perilaku positif lainnya yang terlihat disengaja ataupun sukarela (Hafiz, 2018). Jadi perilaku prososial adalah suatu tindakan yang mendorong seseorang untuk berinteraksi, bekerjasama dan menolong orang lain tanpa mengharapkan suatu imbalan apapun untuk dirinya, serta dapat memberi pengaruh positif kepada si penerima bantuan baik dari segi fisik, psikologis maupun materi.

Perilaku prososial pada masing-masing individu dapat berbeda-beda tergantung pengaruh yang disebabkan oleh faktor-faktor yang mempengaruhi perilaku prososial. Salah satu hal penting yang dapat membentuk tingginya perilaku prososial seseorang adalah komitmen beragama. Sehingga, perilaku prososial akan lebih mudah terjadi dan terus meningkat karena keyakinan dari agama yang dianut (Hanifah \& Stephani, 2021).

Berdasarkan uji analisis deskriptif pada skala husnuzzhan diketahui mahasiswa UIN Antasari Banjarmasin pada kategori rendah sebanyak 12 orang dengan persentase 12,2\%, kategori sedang sebanyak 68 orang dengan persentase 69,4\% dan kategori tinggi sebanyak 18 orang dengan persentase $18,4 \%$. Perilaku seseorang yang tampak secara lahiriyah tejadi 
karena dipengaruhi oleh keyakinan yang dianutnya. Keyakinan agama yang sungguhsunguh akan menghasilkan motivasi yang kuat dalam diri manusia untuk berbuat baik kepada sesama (Arvianna dkk., 2021). Individu yang menerapkan sifat husnuzzhan dalam hidupnya akan mampu menerima segala kondisi apapun bahwa semua yang terjadi dalam hidupnya akan ada hikmah yang dapat diambil.

Husnuzzhan sebagai bentuk evaluasi atau interpretasi seseorang terhadap kehidupan yang dijalaninya. Husnuzzhan membuat hari-hari yang dijalaninya merasa tenang dan tentram karena berpikir bahwa segala sesuatu yang adalah ketentuan dari Allah swt, entah itu baik ataupun buruk mereka selalu menyadari bahwa akan ada hikmah dari setiap proses kehidupan (Anggun Yuniasih, 2017). Rusydi menjelaskan bahwa dengan berpikir positif manusia akan terbebas dari beban hidup dan pengalaman traumatik yang pernah dialami. Hal ini terjadi karena prasangka, keyakinan dan pola pikir sangatlah berpengaruh terhadap realita kehidupan individu (Rusydi, 2012).

Uji analisis deskriptif pada skala perilaku prososial diketahui tingkat perilaku prososial mahasiswa UIN Antasari Banjarmasin berada pada kategori rendah sebanyak 14 orang dengan persentase $14,3 \%$, kategori sedang sebanyak 73 orang dengan persentase $74,5 \%$ dan kategori tinggi sebanyak 11 orang dengan persentase $11,2 \%$. Witri menjelaskan jika perilaku prososial seseorang rendah, maka aspek-aspek yang terkandung di dalam perilaku prososial tidak dapat terealisasikan atau diaplikasikan dalam bentuk perilaku positif bagi kesejahteraan orang lain yang berada disekitarnya. Hal ini terjadi karena adanya nilai-nilai atau pertimbangan lain yang ikut berperan dalam diri seseorang.

Menurut Batson dan Brown menjelaskan bahwa orang yang beragama memiliki kecenderungan yang lebih besar untuk membantu orang lain, dibanding orang yang tidak mengenal agama (Rizaq, 2019). Menurut Eisenberg seseorang yang memiliki perilaku prososial akan menghasilkan sikap tolong menolong antar orang atau kelompok, mengurangi kecenderungan bersikap acuh dan meningkatkan kepedulian terhadap orang lain. Sebaliknya, seseorang yang kurang mempunyai sikap prososial akan menghasilkan sikap acuh atau apatis terhadap lingkungan sekitar (Anjani, 2018).

Selanjutnya, berdasarkan uji hipotesis yang dilakukan diketahui bahwa nilai $\mathrm{F}_{\text {hitung }}=$ 26,950 dengan nilai signifikansi sebesar 0,000 (nilai sig < 0,05) maka hal ini menunjukkan bahwa Ha diterima, sehingga dapat ditarik kesimpulan bahwa terdapat pengaruh yang 
signifikan antar variabel husnuzzhan terhadap variabel perilaku prososial. Dengan nilai korelasi (R) sebesar 0,468 dan nilai koefisien determinasi ( $R$ Square) sebesar 0,219 yang artinya bahwa pengaruh variabel husnuzzhan terhadap variabel perilaku prososial sebesar $21,9 \%$ dan $78,1 \%$ dipengaruhi variabel lain yang tidak termasuk dalam penelitian. Berdasarkan hasil analisis data penelitian tersebut, maka ditarik kesimpulan bahwa terdapat pengaruh yang signifikan antara husnuzzhan terhadap perilaku prososial pada mahasiswa UIN Antasari Banjarmasin. Hal ini sejalan dengan penelitian Nurhafiza dengan judul "Hubungan Religiusitas dengan Sikap Siswa terhadap Perilaku Prososial " bahwa terdapat hubungan positif dan signifikan antara religiusitas dengan sikap siswa terhadap perilaku prososial. Semakin tinggi tingkat religiusitas yang dimiliki siswa maka semakin tinggi tingkat perilaku prososial siswa, sehingga siswa cenderung memunculkan sikap yang positif pada kehidupannya (Nurhafiza, 2019). Penelitian Aridhona (2018) dengan judul "Hubungan Perilaku Prososial dan Religiusitas dengan Moral pada Remaja" menyimpulkan bahwa terdapat hubungan yang signifikan dan positif antara moral dengan perilaku prososial dan religiusitas. Perilaku prososial yang tinggi menunjukkan bahwa remaja mengalami perkembangan moral dalam rentang kehidupannya sehingga remaja mampu menyesuaikannya (Aridhona, 2018). Penelitian lainnya yang dilakukan Arvianna, Mashabi dan Hasanah (2021) dengan judul "Hubungan antara Religiusitas dengan Perilaku Prososial pada Remaja di Perumahan Patria Jaya" terdapat korelasi positif antara Religiusitas dengan Perilaku Prososial yang berarti semakin tinggi religiusitas remaja maka semakin tinggi perilaku prososial remaja. (Arvianna dkk., 2021).

Perilaku prososial adalah gambaran dari terjalinnya lingkup sosial yang baik, sehingga memunculkan sikap individu yang peduli akan sesama dan adanya toleransi yang terjalin antar individu (Arvianna dkk., 2021). Individu yang memiliki prasangka baik kepada sesamanya akan membangun hubungan yang baik dengan orang lain, karena prasangka, pola pikir dan keyakinan seseorang berpengaruh terhadap realita kehidupannya (Rusydi, 2012). Seperti hadits qudsy yang memiliki arti:

"Sesungguhnya Allah swt berkata: aku mengikuti prasangka hamba-Ku, apabila prasangkanya baik maka kondisinya akan menjadi baik, apabila prasangkanya buruk, maka kondisinya akan menjadi buruk" 
Mahasiswa yang mampu menerapkan sifat husnuzzhan dalam kehidupan sehari-hari, pasti mampu menerapkan perilaku prososial di lingkungan masyarakat atau kampus. Karena sifat husnuzzhan sangat membantu untuk menghilangkan ketakutan dan kekhawatiran seseorang terhadap sesuatu. Sehingga ketika seseorang melakukan tindakan prososial tidak memiliki perasaan was-was atau khawatir, sebab dia selalu berpikir positif kepada orang lain tanpa ada rasa curiga sedikitpun. Jika seseorang yang memiliki tingkat husnuzzhan yang tinggi maka akan mudah baginya untuk berperilaku prososial. Hal ini menunjukkan bahwa husnuzzhan merupakan salah satu faktor yang memberikan kontribusi terhadap tinggi rendahnya perilaku prososial seseorang. Perilaku prososial yang terbaik ialah yang didasarkan karena Allah swt, yakni dilaksanakan dengan niat yang tulus karena Allah dan dengan cara yang sopan, empati dan simpatik. Artinya tindakan sosial yang dilakukan baik berupa bantuan fisik, dukungan moral maupun psikologis benar-benar dilaksanakan dengan motivasi ikhlas karena Allah swt.

Keterbatasan dalam penelitian ini terdapat pada wawancara yang dilakukan, peneliti hanya melakukan wawancara untuk studi pendahuluan dan tidak melakukan wawancara untuk memperkuat hasil penelitian.

\section{Kesimpulan}

Berdasarkan hasil analisis data penelitian diketahui tingkat husnuzzhan mahasiswa UIN Antasari Banjarmasin berada pada kategori sedang. Yang berada pada kategori rendah sebanyak 12 orang dengan persentase $12,2 \%$, kategori sedang sebanyak 68 orang dengan persentase $69,4 \%$ dan kategori tinggi sebanyak 18 orang dengan persentase 18,4\%. Selanjutnya untuk hasil analisis data perilaku prososial mahasiswa UIN Antasari Banjarmasin berada pada kategori sedang. Yang berada pada kategori rendah sebanyak 14 orang dengan persentase $14,3 \%$, kategori sedang sebanyak 73 orang dengan persentase $74,5 \%$ dan kategori tinggi sebanyak 11 orang dengan persentase $11,2 \%$. Pada hasil uji korelasi diketahui bahwa nilai $\mathrm{F}_{\text {hitung }}=26,950$ dengan nilai signifikansi sebesar 0,000 $<0,05$ maka hal ini menunjukkan bahwa Ha diterima, sehingga dapat ditarik kesimpulan bahwa terdapat pengaruh yang signifikan antar variabel husnuzzhan terhadap variabel perilaku prososial. Dengan nilai korelasi $(R)$ sebesar 0,468 dan nilai koefisien determinasi ( $R$ Square) sebesar 0,219 yang artinya bahwa pengaruh variabel husnuzzhan terhadap variabel perilaku 
prososial sebesar $21,9 \%$ dan $78,1 \%$ dipengaruhi variabel lain yang tidak termasuk dalam penelitian.

Saran

Dari hasil penelitian yang telah dilaksanakan, peneliti menyadari masih terdapat kekurangan pada penelitian ini. Oleh sebab itu, saran yang peneliti berikan ini dapat dijadikan sebagai bahan pertimbangan untuk penyempurna peneliti selanjutnya yang nantinya akan melakukan penelitian terkait husnzzhan dan perilaku prososial, yaitu: Bagi peneliti selanjutnya, hasil penelitian sebesar 78,1\% perilaku prososial dipengaruhi faktor lain. Sehingga bagi peneliti selanjutnya, diharapkan dapat meneliti variabel-variabel lain yang dapat mempengaruhi perilaku prososial, misalnya faktor internal: empati, mood, daya tarik. Sedangkan faktor eksternal: kehadiran orang lain, pengamalan, dll. Serta dapat mengawasi pengisian kuesioner secara langsung agar dapat menjelaskan pernyataan secara rinci.

\section{Referensi}

Amanda, R., \& Mardianto. (2014). Hubungan Antara Prasangka Masyarakat Terhadap Muslimah Bercadar Dengan Jarak Sosial. Jurnal RAP UNP, 5(1), 72-81.

Anggun Yuniasih. (2017). Pengaruh Husnuzzhan Terhadap Psychological Well-Being Pada Remaja di Panti Asuhan PSM (Pesantren Sabilil Muttaqin) Tulungagung [Skripsi]. Institut Agama Islam Negeri Tulungagung.

Anjani, K. Y. (2018). Hubungan Antara Empati Dengan Perilaku Prososial Pada Siswa Swasta X di Surabaya. 05(02), 1-6.

Anwar, R. (2010). Akhlak Tasawuf. Pustaka Setia.

Aridhona, J. (2018). Hubungan Perilaku Prososial dan Religiusitas dengan Moral pada Remaja. Konselor, 7(1), 21-25.

Arvianna, L. F., Nurlaila A. Mashabi, \& Uswatun Hasanah. (2021). Hubungan Antara Religiusitas Dengan Perilaku Prososial Pada Remaja di Perumahan Patria Jaya. JKKP : Jurnal Kesejahteraan Keluarga dan Pendidikan, 8(1), 67-80.

Daniprawiro, M. (2009). Menipisnya Budaya Tradisional (96 ed.). Gemari.

Faliyandra, F. (2019). Konsep Kecerdasan Sosial Goleman dalam Perspektif Islam (Sebuah Kajian Analisis Psikologi Islam). Jurnal Inteligensia, 7(2), 1-24.

Hafiz, S. E. dkk. (2018). Psikologi Sosial: Pengantar dalam Teori dan Penelitian. Salemba Humanika. 
Hanifah, F. D., \& Stephani Raihana Hamdan. (2021). Kontribusi Religiusitas Terhadap Perilaku Prososial Guru Sekolah Inklusi Berbasis Islam. JPIB : Jurnal Psikologi Islam dan Budaya, 4(1), 67-80.

Hanurawan, F. (2018). Psikologi Sosial Terapan untuk Pemecahan Masalah Perilaku Sosial. Rajawali Pers.

Muh Miftachur Rizaq. (2019). Hubungan Religiusitas Dengan Perilaku Prososial Siswa Kelas XII MA Al Asror Gunung Pati Semarang Tahun Pelajaran 2018/2019 [Skripsi]. Universitas Negeri Semarang.

Nurhafiza. (2019). Hubungan Religiusitas dengan Sikap Siswa terhadap Perilaku Prososial. Biblio Couns : Jurnal Kajian Konseling dan Pendidikan, 2(2), 67-71.

Rusydi, A. (2012). Husn Al-Zhann: Konsep Berpikir Positif dalam Perspektif Psikologi Islam dan Manfaatnya bagi Kesehatan Mental. Proyeksi, 7(1), 1-31.

Sagir, A. (2009). Husnuzzhan dalam Perspektif Psikologi. Antasari Press.

Tim Penulis Fakultas Psikologi UI. (2011). Psikologi Sosial. Salemba Humanika.

Yantiek, E. (2014). Kecerdasan Emosi, Kecerdasan Spiritual Dan Perilaku Prososial Remaja. Persona (Jurnal Psikologi Indonesia), 3(01), 22-31.

\begin{tabular}{|l|l|l|l|l|}
\hline Submit & Review & Revisi & Diterima & Publis \\
\hline 22-07-2021 & 1) $20-08-2021$ s.d. $24-08-2021$ & 1) $04-10-2021$ & $3-11-2021$ & $04-02-2022$ \\
& 2) $21-10-2021$ s.d. $25-10-2021$ & 2) $02-11-2021$ & & \\
\hline
\end{tabular}

\footnotetext{
Mariatul Kiftiah, Mubarak, Yulia Hairina

Program Studi Psikologi Islam

Fakultas Ushuluddin dan Humaniora

Universitas Islam Negeri Antasari Banjarmasin

Email: mariatul.kiftiah1998@gmail.com
} 